\title{
Isolation and Characterization of Rabbit Kidney Brush Borders
}

\author{
By S. J. QUIRK and G. B. ROBINSON \\ Department of Biochemistry, University of Oxford, South Parks Road, Oxford OX1 3QU, U.K.
}

\author{
(Received 3 March 1972)
}

\begin{abstract}
1. Brush borders were isolated from rabbit kidney-cortex homogenates by rate-zonal centrifugation through a sucrose density gradient in a B-XIV zonal rotor, followed by differential centrifugation. 2. The method of preparation gave brush borders of high purity with a reasonable yield. The morphological appearance supported the evidence from enzymic and chemical investigations, that the brush borders were only slightly contaminated with endoplasmic reticulum, mitochondria, lysosomes and nuclei. 3 . The molar ratio of cholesterol to phospholipid lay within the range found in other plasma membranes, but the carbohydrate content was double that found in liver plasma membranes. 4. Alkaline phosphatase, maltase, trehalase and aminopeptidase were major enzymic constituents of the brush borders, and had an approximately equal yield and enrichment, but none of these enzymes fulfilled the criteria for marker enzymes. 5. $\mathrm{Mg}^{2+}$-dependent and $\mathrm{Na}^{+}, \mathrm{K}^{+}$-dependent adenosine triphosphatases, although found in brush borders, had low yields and low enrichments.
\end{abstract}

The functioning of the kidney is understood in physiological terms but biochemical studies have been hindered because each nephron, the physiological unit of the kidney, contains a diversity of cells with differing functions, and the individual cell types cannot readily be studied in isolation. The proximal tubule of the nephron is responsible for the reabsorption of the major portion of the glomerular filtrate (Pitts, 1968). The apical surfaces of the proximal tubule epithelial cells are morphologically specialized, having numerous well-defined microvilli or brush borders (Rhodin, 1958). Since the brush borders are confined to one type of cell which has a well-defined function, the development of methods for isolating these organelles will permit studies of their biochemistry with the eventual aim of relating these findings to physiological function. For this purpose, the material obtained must be unambiguously identified as brush borders and the preparation should contain little or no contamination.

Similar morphological specialization is a feature of epithelial cells of the small intestine, another important absorptive surface. Brush borders were first isolated from this tissue by Miller \& Crane (1961) and biochemical studies have established that they contain alkaline phosphatase, leucine aminopeptidase, disaccharidases, and $\mathrm{Mg}^{2+}$-dependent and $\mathrm{Na}^{+}, \mathrm{K}^{+}$dependent adenosine triphosphatases (Eicholz, 1967; Forstner et al., 1968a; Quigley \& Gotterer, 1969).

Kidney plasma membranes, of predominantly vesicular morphology and various degrees of purity, have been prepared from rat kidney homogenates (Binkley et al., 1968; Manitus et al., 1968; Fitzpatrick et al., 1969), and rat and rabbit kidney-cortex brush borders were first isolated by isopycnic centrifugation (Thuneberg \& Rostgaard, 1968), although no biochemical characterization was attempted. Several authors have since isolated brush borders from rat (Kinne \& Kinne-Saffran, 1969; Wilfong \& Neville, 1970) and rabbit (Berger \& Sacktor, 1970) kidney cortex under isopycnic conditions, and described some of their enzymic constituents.

The present study employed rate-separation conditions in a zonal rotor, followed by differential centrifugation, to obtain a brush-border preparation essentially free from contamination by other organelles as judged by morphological and enzymic criteria. The enzymic and chemical characteristics of the brush borders were studied, and the problem of the presence within brush borders of possible marker enzymes is examined in the light of the present knowledge of enzymic distributions within the nephron.

\section{Experimental}

\section{Isolation of brush borders from rabbit kidney cortex}

The method of isolation is portrayed in Scheme 1. Rabbits (2-3 kg, Blue Bevron $\times$ Chinchilla) obtained from the Oxford University Farm, U.K. were anaesthetized with Nembutal. The kidneys were perfused with $0.15 \mathrm{M}-\mathrm{NaCl}$, before being removed and chilled to $0^{\circ} \mathrm{C}$. They were then decapsulated and the cortices were separated. All subsequent procedures were done at $4^{\circ} \mathrm{C}$.

The tissue $(10-20 \mathrm{~g})$ was minced finely with scissors and homogenized with a Silverson mixeremulsifier (Silverson Machines Ltd., London, S.E.1, 
(I) Initial homogenate

(Silverson mixer-emulsifier)

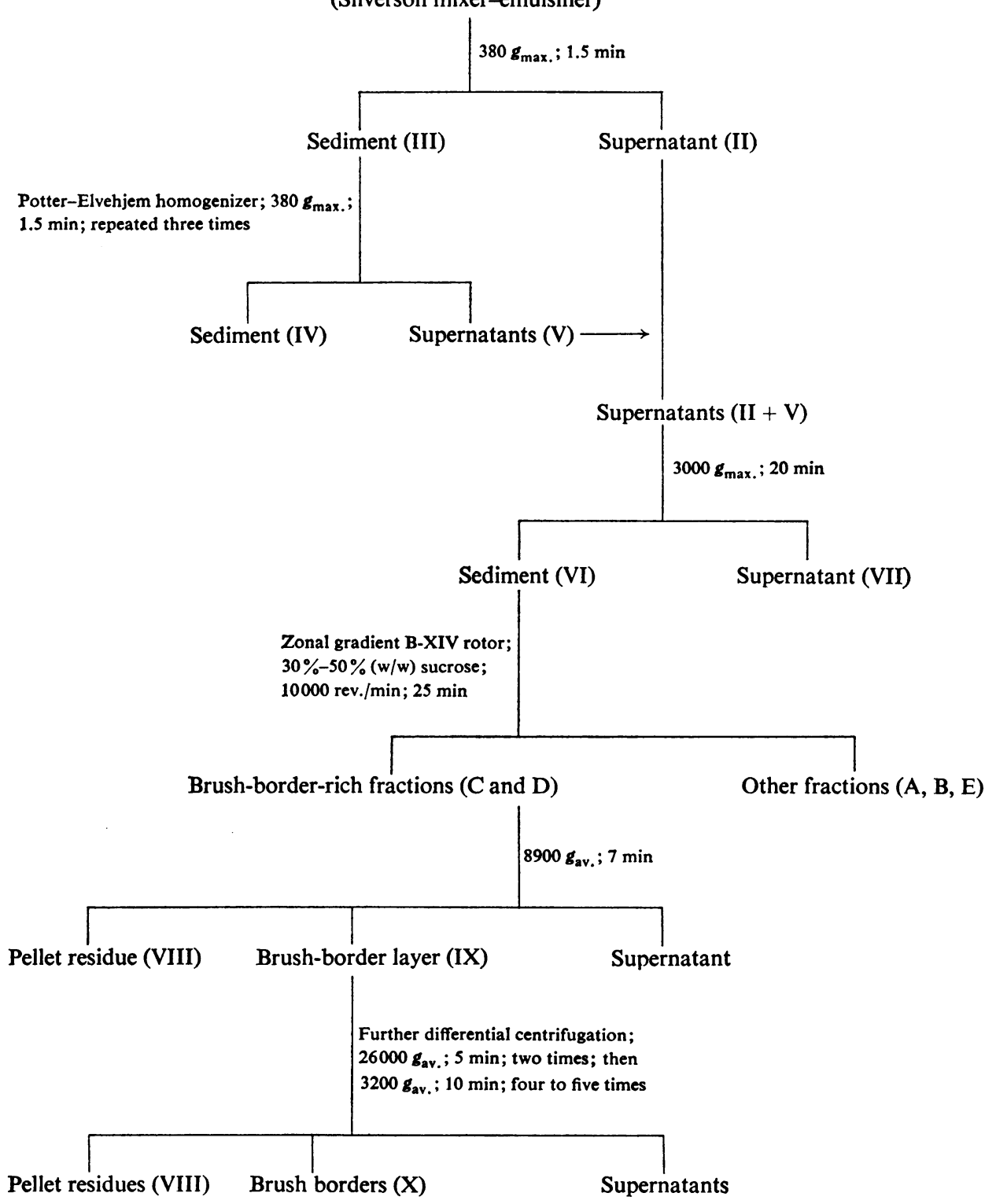

Scheme 1. Isolation of rabbit kidney cortex brush borders

U.K.) in $0.5 \mathrm{M}$-sucrose $(5-7 \mathrm{~g}$ of tissue $/ 40 \mathrm{ml})$ for $45 \mathrm{~s}$ at two-thirds maximum speed. The initial homogenate (I) was stirred with a glass-rod for $2 \mathrm{~min}$ to remove air bubbles, centrifuged (M.S.E. Mistral 6L centrifuge, angle rotor 69167$)$ at $380 \mathrm{~g}_{\max }$ for $1.5 \mathrm{~min}$ and the supernatant (II) retained. The supernatant sometimes contained some tubules and if so, it was re-centrifuged. The sediment (III) from the first centrifugation was subjected to further homogenization by using three strokes in a Potter-Elvehjem homogenizer (clearance $0.13 \mathrm{~mm}$ ) in $0.5 \mathrm{M}$-sucrose $(40 \mathrm{ml})$. This homogenate was centrifuged as above and the supernatant $(\mathrm{V})$ retained. Re-homogenization and centrifugation was repeated twice more. The 
retained supernatants (II and V) from these centrifugations were combined, strained through two layers of gauze and centrifuged at $3000 \mathrm{~g}_{\max }$. for $20 \mathrm{~min}$. The resulting multilayered sediment (VI) was suspended in $50-60 \mathrm{ml}$ of $0.5 \mathrm{M}$-sucrose with one stroke of the Potter-Elvehjem homogenizer.

This suspension was layered on to a linear gradient (with respect to volume) prepared from $230 \mathrm{ml}$ of $30 \%(\mathrm{w} / \mathrm{w})$ sucrose and $230 \mathrm{ml}$ of $50 \%(\mathrm{w} / \mathrm{w})$ sucrose in a Beckman B-XIV Al zonal rotor. Sucrose $(55 \%$, $\mathrm{w} / \mathrm{w})$ was used as underlay and $0.25 \mathrm{M}$-sucrose $(40 \mathrm{ml})$ was used as overlay. Loading and unloading the rotor was conducted at $2000 \mathrm{rev}$./min with pumping rates of $45 \mathrm{ml} / \mathrm{min}$, the sample being introduced at the rate of $10 \mathrm{ml} / \mathrm{min}$. The rotor was run at $10000 \mathrm{rev} . / \mathrm{min}$ for $25 \mathrm{~min}\left(\omega^{2} t=1.64 \times 10^{9}\right)$ and was decelerated with the brake on. Portions $(16 \mathrm{ml})$ were collected, examined by phase-contrast microscopy and those portions containing brush borders, typically tube numbers 8-18 (30-38\% sucrose), were pooled and diluted with ice-cold water to a sucrose concentration of about $0.5 \mathrm{M}$, and then centrifuged (No. 30 rotor, Beckman model $L$ centrifuge) at $8900 g_{\text {av }}$. for $7 \mathrm{~min}$. The supernatant containing small fragments of brush borders, membranes and vesicles was discarded. The brush borders formed a loose white fluffy surface layer (IX), which was removed from the pellet with a Pasteur pipette, and the pellet surface was washed carefully with $1 \mathrm{ml}$ of $0.5 \mathrm{M}$-sucrose; the two lower pellet layers, described as the pellet residue (VIII) were discarded. The brush-border-rich layer (IX) was resuspended in $0.5 \mathrm{M}$-sucrose and centrifuged twice at $26000 \mathrm{~g}_{\mathrm{av}}$ for $5 \mathrm{~min}$ (No. 40 rotor, Beckman). Further centrifugations were then conducted at $3200 \mathrm{~g}_{\mathrm{av}}$. for $10 \mathrm{~min}$. In all these centrifugations the pellet formed three layers as before, but the two lower layers progressively diminished in size. The top brush-border-rich layer was removed each time as described above and the pellet residues (VIII) were discarded. Centrifugation was continued until no pellet residue was observed; four centrifugations were normally sufficient. The final brush-border pellet (X) was suspended in $0.5 \mathrm{M}$-sucrose for morphological, chemical and enzymic analysis.

In experiments where the recoveries of enzymes were measured at each stage of the purification, the proportions collected from the gradient were separated according to their microscopic appearance into five groups designated fractions (A) to (E). Fraction (A), at the lowest sucrose density, contained small vesicles; fraction (B) contained vesicles and small mitochondria; fraction (C) contained small and medium-size brush borders and large mitochondria; fraction (D) contained large brush borders; fraction (E) contained tubule fragments and nuclei. Fractions (A) and (B) were diluted to a sucrose concentration of $0.5 \mathrm{M}$ and were analysed. Fractions (C) and (D) were individually processed as described in the previous paragraph to give brush-border fractions (C-X) and (D-X), together with their two corresponding pellet-residue fractions (C-VIII) and (D-VIII). These samples were retained for analysis; the supernatants from the centrifugations were found not to contain disaccharidase activity and were discarded. Fraction (E) was not analysed.

\section{Enzyme determinations}

All enzyme assays were performed under zero-order rate conditions.

Alkaline phosphatase (EC 3.1.3.1). The assay system contained $40 \mathrm{~mm}$-ethanolamine- $\mathrm{HCl}$ buffer, pH 10.5, 40mm-sodium $\beta$-glycerophosphate, $\mathrm{pH} 10.5$, $5 \mathrm{mM}-\mathrm{MgCl}_{2}, 1 \mathrm{~mm}-\mathrm{KF}$ and incubation was at $37^{\circ} \mathrm{C}$. The reaction was stopped with $0.5 \mathrm{vol}$. of $15 \%(\mathrm{w} / \mathrm{v})$ trichloroacetic acid and $\mathbf{P}_{\mathbf{1}}$ was measured on a sample of the supernatant after centrifugation.

Adenosine triphosphatase (EC 3.6.1.3). Total adenosine triphosphatase activity was determined at $37^{\circ} \mathrm{C}$ by using a reaction mixture containing $100 \mathrm{mM}-\mathrm{NaCl}$, $20 \mathrm{~mm}-\mathrm{KCl}, 5 \mathrm{~mm}-\mathrm{MgCl}_{2}, 20 \mathrm{~mm}$-imidazole buffer, pH7.5, and 5mM-ATP (sodium salt), pH7.5. The reaction was stopped with a $0.5 \mathrm{vol}$. of $15 \%(\mathrm{w} / \mathrm{v})$ trichloroacetic acid and $P_{i}$ was determined on a sample of the supernatant after centrifugation. Ouabain-insensitive adenosine triphosphatase $\mathrm{Cg}^{2+}$ dependent adenosine triphosphatase) activity was measured as above but in the presence of $1 \mathrm{~mm}$ ouabain. The $\mathrm{Na}^{+}, \mathrm{K}^{+}$-dependent adenosine triphosphatase activity was taken to be the difference between total adenosine triphosphatase and ouabaininsensitive adenosine triphosphatase activities.

Glucose 6-phosphatase (EC 3.1.3.9). This enzyme was assayed by the method of Hübscher \& West (1965).

Succinate dehydrogenase. This enzyme was assayed by the method of Pennington (1961) with 2-(p-iodophenyl) - 3 - ( $p$ - nitrophenyl) - 5 - phenyltetrazolium chloride as acceptor.

Acid phosphatase (EC 3.1.3.2). The activity of this enzyme was measured by using $50 \mathrm{~mm}$-sodium acetate buffer, pH 5.6, and $100 \mathrm{~mm}$-sodium $\beta$-glycerophosphate at $37^{\circ} \mathrm{C}$. The enzyme samples were preincubated with $0.1 \%(v / v)$ Triton $\mathrm{X}-100\left(15 \mathrm{~min}, 0^{\circ} \mathrm{C}\right)$ before addition to the reaction mixture. The reaction was stopped by the addition of $0.5 \mathrm{vol}$. of $15 \%(\mathrm{w} / \mathrm{v})$ trichloroacetic acid and $\mathbf{P}_{\mathbf{i}}$ was measured in the supernatant after centrifugation.

Maltase and trehalase (EC 3.2.1.28). Assays were an adaptation of the method of Dahlqvist (1968). The reaction mixture contained $50 \mathrm{~mm}$-maleate buffer, pH 6.25, $28 \mathrm{~mm}$-maltose or trehalose and incubation was at $37^{\circ} \mathrm{C}$. After an appropriate time interval, glucose was determined in the reaction mixture by adding $2.5 \mathrm{vol}$. of tris-glucose oxidase reagent and incubating for $60 \mathrm{~min}$ at $37^{\circ} \mathrm{C}$. Tris-glucose oxidase 
reagent contained $100 \mathrm{ml}$ of $0.5 \mathrm{M}$-tris $-\mathrm{HCl}$ buffer, pH7.0, $12.5 \mathrm{mg}$ of glucose oxidase [type II; Sigma (London) Chemical Co. Ltd., Kingston-uponThames, U.K.], $4 \mathrm{mg}$ of peroxidase (type II; C. F. Boehringer und Soehne G.m.b.H., Mannheim, Germany) and $0.5 \mathrm{ml}$ of $1 \% \mathrm{o}$-dianisidine in $95 \%$ ethanol.

Aminopeptidase (EC 3.4.1.2). The reaction mixture contained $50 \mathrm{~mm}$-potassium phosphate buffer, $\mathrm{pH} 7.0$, and $1.6 \mathrm{~mm}$-leucine $p$-nitroanilide. Incubation was at $37^{\circ} \mathrm{C}$ and the reaction was stopped by adding $0.5 \mathrm{vol}$. of $5 \%(\mathrm{w} / \mathrm{v}) \mathrm{ZnSO}_{4}$. The $p$-nitroaniline released in the reaction was measured in the supernatant at $405 \mathrm{~nm}$ after centrifugation. $p$-Nitroaniline standards were similarly treated with $\mathrm{ZnSO}_{4}$.

\section{Chemical determinations}

Protein was measured by the method of Lowry et al. (1951) with bovine serum albumin (3 times crystallized) as standard. Lipids were extracted from brush-border suspensions with $20 \mathrm{vol}$. of chloroformmethanol $(2: 1, \mathrm{v} / \mathrm{v})$ at room temperature overnight and the pellet was re-extracted twice with $5 \mathrm{vol}$. The combined extracts were partitioned against $\mathrm{CaCl}_{2}$ by the method of Folch et al. (1957) and the lower lipid phase was fractionated by silicic acid chromatography (Bezman-Tarcher et al., 1965) into neutrallipid and phospholipid fractions. Total cholesterol was determined on the neutral-lipid fraction after alkaline hydrolysis by the Lieberman-Burchard reaction (Stadtman, 1957). Phospholipid was determined by digestion of a sample of the phospholipid fraction with $70 \%(w / v) \mathrm{HClO}_{4}$ followed by $\mathrm{P}$ determination by either the method of Bartlett (1959) or King (1932). Phospholipid was calculated assuming $25 \mu \mathrm{g}$ of phospholipid $/ \mu \mathrm{g}$ of lipid P (Kopaczyk et al., 1966). Neutral sugars, amino sugars, and $N$-acetylneuraminic acid were determined by g.l.c. (Clamp et al., 1970) on brush borders treated by trichloroacetic acid precipitation followed by delipidation. A Unicam series 104 chromatograph was used with twin columns of $3 \%$ SE 30 on Diatoport S, 80/100 mesh, programmed from $140-220^{\circ} \mathrm{C}$ at $1{ }^{\circ} \mathrm{C} / \mathrm{min}$. DNA (Burton, 1956) and RNA (Schneider, 1957) was determined on trichloroacetic acid hydrolysates of the brush borders (Schneider, 1957). Deoxyribose and ribose were used as the respective standards. The weight of DNA was calculated by multiplying deoxyribose $(\mu \mathrm{mol})$ by 4.88 .

\section{Electron microscopy}

Pellets were fixed for $2 \mathrm{~h}$ in $10 \%(v / v) p$-formaldehyde-10\% (v/v) glutaraldehyde in $0.1 \mathrm{M}$-sodium phosphate buffer, $\mathrm{pH} 7.3$, containing $0.1 \% \mathrm{CaCl}_{2}$, before being washed overnight in $7 \%(\mathrm{w} / \mathrm{v})$ sucrose in phosphate buffer, $\mathrm{pH} 7.3$, and stained in $2 \%$ (w/v) osmium tetroxide in $0.1 \mathrm{M}$-sodium phosphate buffer. Specimens were dehydrated and embedded in Araldite epoxy resin. Thin sections were cut with an LKB ultra-microtome, and were stained with uranyl acetate and lead citrate, and examined in a Siemens Elmiskop 101 microscope.

\section{Results and Discussion}

\section{Fractionation technique}

Homogenization. Initial perfusion of the kidneys was essential, since brush borders prepared from nonperfused kidneys were pink instead of white, indicating contamination with haemoglobin. The brush borders were mechanically fragile so that homogenization was inevitably a compromise between attempting to obtain high yields and minimizing disruption of the organelles. The initial homogenization with the Silverson mixer-emulsifier, a rotating blade homogenizer, released approx. $50 \%$ of the alkaline phosphatase from the tissue, but prolonged homogenization by this technique diminished the final yield of brush borders. Microscopic examination of supernatant (II) showed it to contain brush borders, mitochondria, some nuclei, small tubule fragments and vesicles, whereas the sediment (III) contained glomeruli, undisrupted tubules and most of the nuclei.

To release brush borders from the undisrupted tubules, the sediment (III) was briefly homogenized in a Potter-Elvehjem homogenizer and again centrifuged. This step was repeated three times in all and the supernatants $(\mathrm{V})$ containing free brush borders were retained. This technique minimized the disruption of brush borders after release from the tubules by decreasing the duration of their exposure to homogenization. The combined supernatants (II+V) contained approximately $50-85 \%$ of the protein, alkaline phosphatase, maltase, trehalase, succinate dehydrogenase and glucose 6-phosphatase (Table 1). The brush borders were recovered from the combined supernatants by centrifugation at $3000 \mathrm{~g}_{\max }$. for $20 \mathrm{~min}$. This sediment (VI) contained only $17 \%$ of the initial glucose 6-phosphatase activity as compared with $63 \%$ in the combined supernatants, whereas the protein content decreased from 73 to $21 \%$. Alkaline phosphatase, maltase, trehalase and succinate dehydrogenase were decreased to between 40 $60 \%$ of the initial activity suggesting that the homogenization steps, in spite of precautions, appreciably fragmented the brush borders and other membranes.

Zonal centrifugation. In preliminary studies, several different conditions were used to try and resolve brush borders from mitochondria and other contaminants. Kidney mitochondria are known to exhibit a wide diversity of size and shape (Rhodin, 


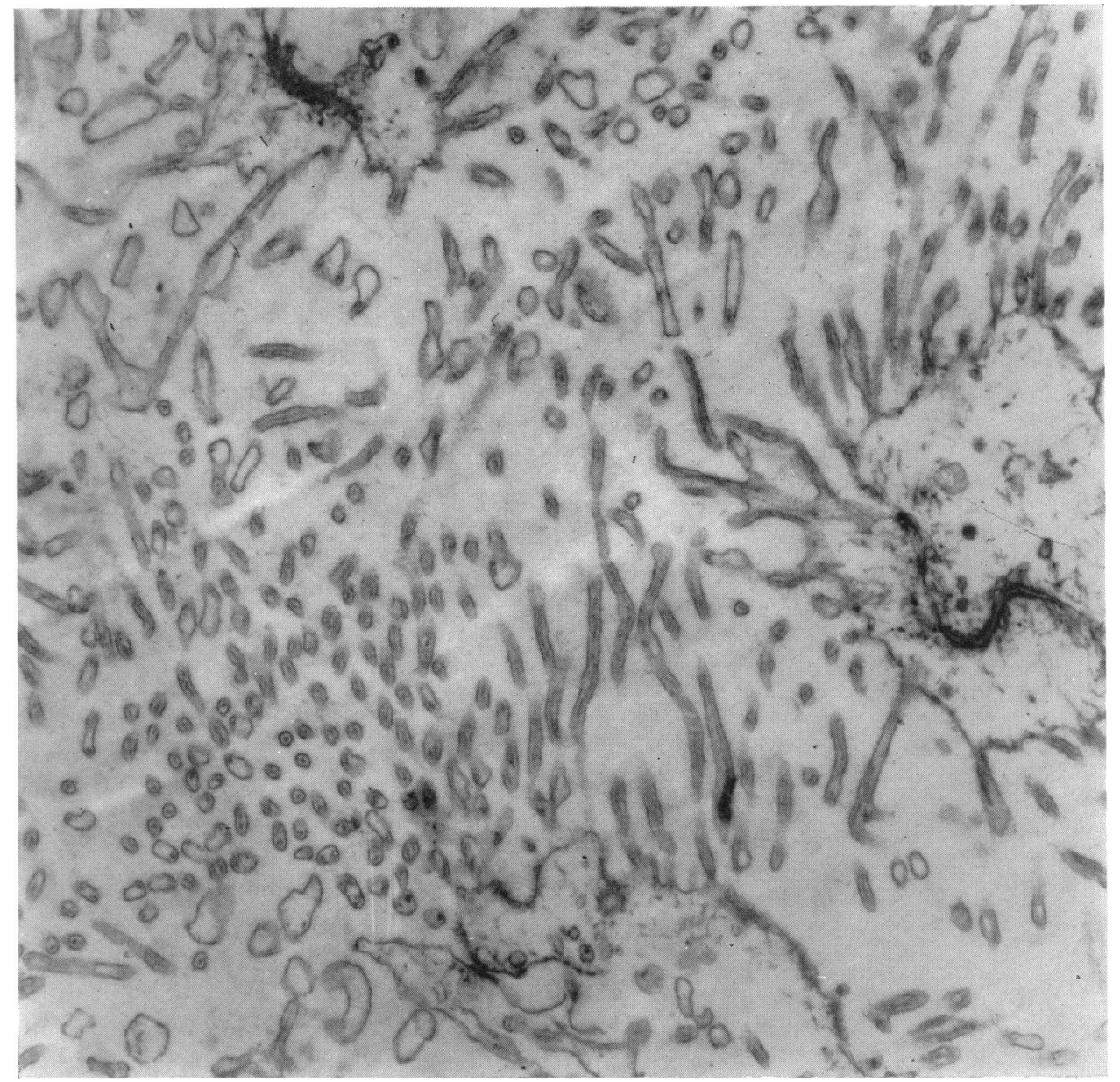

\section{EXPLANATION OF PLATE I}

Sectioned pellet of the brush-border preparation

Terminal webs are present at the top, bottom and right of the plate. Most microvilli, cut both tangentially and obliquely, emanate from the terminal web at the bottom of the plate. Microvilli have a noticeable central core. A terminal bar can be seen at the top left $(\times 14000)$. 


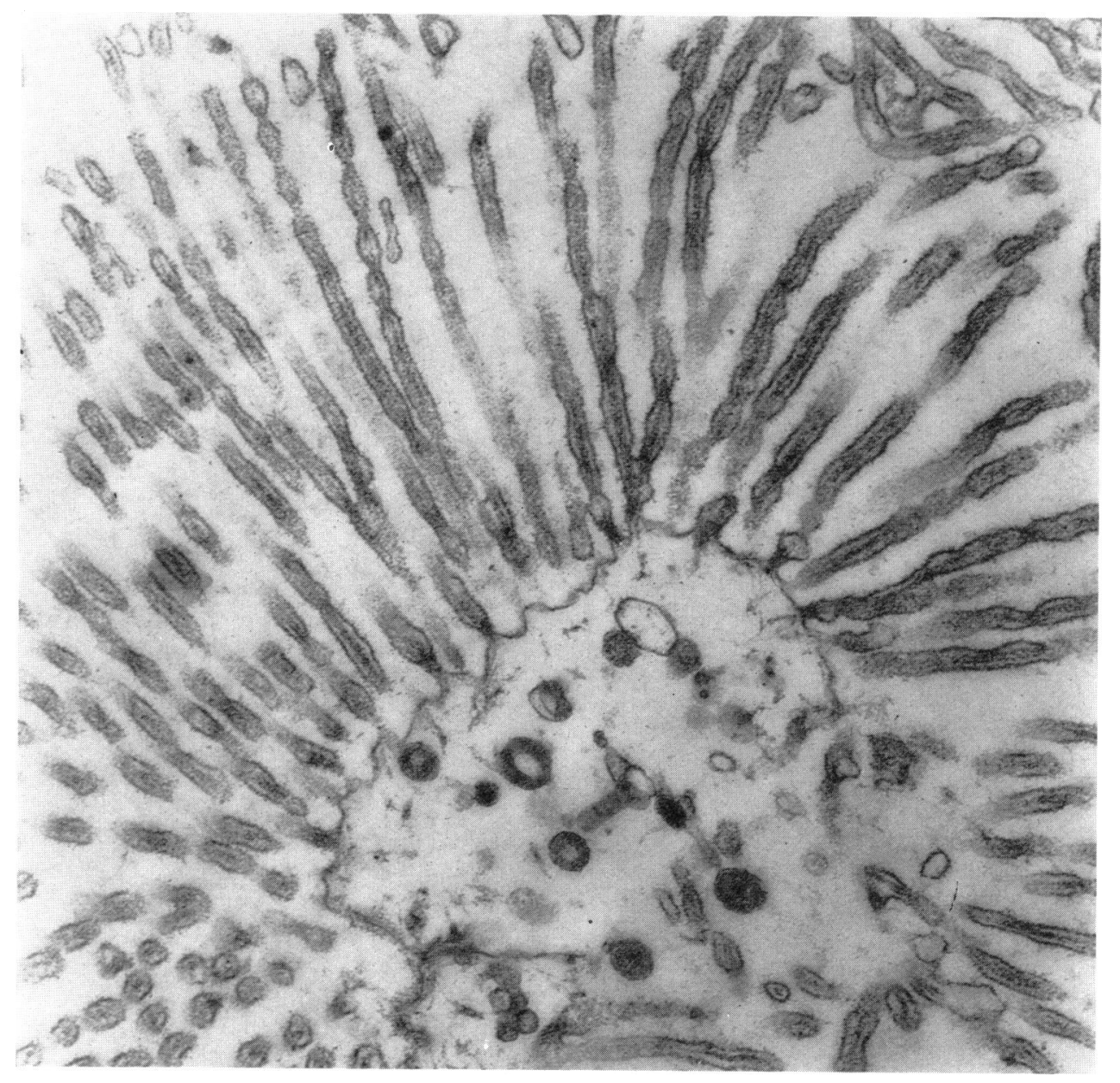

EXPLANATION OF PLATE 2

Sectioned pellet of the brush-border preparation

One brush-border fragment is seen with many radiating microvilli each with a prominent central core. Glycocalyx is apparent at the surface of the microvilli and a few tubules are associated with the base of the brush border $(\times 35000)$. 
1958) and their buoyant density overlaps that of brush borders. Accordingly a rate-zonal rather than isopycnic method of separation was adopted, since this was found to give an adequate if incomplete separation of the two organelles and had a further advantage in that a short centrifugation time could be used. The microscopic appearance of fractions (A)(E) was described in the Experimental section, and enzyme assays of these fractions showed that alkaline phosphatase, maltase and trehalase were predominantly in fractions (A), (C) and (D), whereas succinate dehydrogenase was in fractions (A), (B) and (C). Glucose 6-phosphatase activity was confined to fraction (A) (Table 1).

Differential centrifugation. The triple-layered pellets resulting from the centrifugation of fractions $(C)$ and (D) consisted of a white fluffy upper layer (IX) overlying a yellow translucent layer and a dark-yellow pellet; these two latter layers were the pellet residue (VIII). The upper layer contained mainly brush borders with some mitochondria, whereas the yellow translucent layer was of heterogeneous composition with some brush borders, other membranous elements and a few mitochondria. The dark-yellow lower pellet consisted of mitochondria. Presumably this stratification of the pellet was a consequence of the difference in shape between the mitochondria and the brush borders, the more regular mitochondria forming a discrete tightly-packed pellet which was overlaid by the irregular brush borders. This phenomenon was used to remove the mitochondria and other contaminants from the brush-border preparation by repeated centrifuging until no pellet residue was visible, when phase-contrast microscopy showed that the preparation was essentially pure.

The process was effective but resulted in appreciable losses of alkaline phosphatase and disaccharidase (Table 1). The pellet residues, when totalled together, (C-VIII+D-VIII) contained percentages of the original activity as follows: alkaline phosphatase, $11 \%$, maltase, $5 \%$; trehalase, $4 \%$; succinate dehydrogenase, $2 \%$; glucose 6-phosphatase, $0.2 \%$. The brushborder preparation $(\mathbf{C}-\mathbf{X}+\mathbf{D}-\mathbf{X})$ contained in total: alkaline phosphatase, $7 \%$; maltase, $7.5 \%$; trehalase, $5 \%$; succinate dehydrogenase, $0.025 \%$; glucose $6-$ 6-phosphatase, $0.06 \%$ (Table 1). These results indicated only minor contamination of the brush borders by mitochondria and endoplasmic reticulum.

Examination of the results in Table 1 shows that alkaline phosphatase and the disaccharidases behaved differently during the purification. Less disaccharidase was recovered from the zonal centrifugation than alkaline phosphatase, whereas more alkaline phosphatase was lost to the pellet residues during the purification of brush borders from the zonal fractions. These results indicate that disaccharidases are located differently from alkaline phosphatase in the kidney cortex.

\section{Analysis of brush-border preparations}

Morphological evaluation. Phase-contrast microscopy of brush-border preparations showed large and medium-sized brush borders having a 'hedgehog' or stellate appearance with prominent microvilli. A dark terminal bar was clearly visible at the base of the microvilli. Sometimes, adhering cytoplasmic material integral with the brush borders was seen, which occasionally entrapped small mitochondria. Mitochondria and membrane vesicles were observed rarely.

Electron micrographs showed well-defined brush borders with many microvilli radiating from the terminal web; apical inclusions could be seen basal to the microvilli (Plates 1 and 2). A prominent central core was seen when the microvilli were cut normal to the microvillus axis. A fuzzy coating was noticeable at the outer periphery of the microvillus membrane. Thus the appearance of the isolated brush borders is very similar to electron micrographs of the apical portion of proximal tubule cells in situ in the kidney cortex. Such well-defined microvilli are known to be confined to the proximal tubules (Rhodin, 1958).

Chemical analyses. The molar ratio of cholesterol to phospholipid is significantly higher in rat liver plasma membranes than in cytoplasmic membranes (Coleman, 1968; Keenan \& Morré, 1970). Accordingly a high molar ratio has been taken to indicate low contamination of plasma-membrane fractions by cytoplasmic membranes. Studies on guinea-pig kidney plasma membranes, estimated to be $20-30 \%$ contaminated with mitochondria and endoplasmic reticulum, gave a cholesterol to phospholipid molar ratio of 0.5 (Coleman \& Finean, 1966). In other isolated plasma membranes, the values for the molar ratio have been reported as follows; the values determined more recently tend to be higher: rat intestinal brush borders, 0.46-1.3 (Ashworth \& Green, 1966; Eichholz, 1967; Forstner et al., 1968b); rat liver plasma membranes, 0.63-0.90 (Benedetti \& Emmelot, 1968; Ray et al., 1969; Henning et al., 1970, Touster et al., 1970). Thus the value obtained in the present study, 0.65 , for the cholesterol to phospholipid molar ratio in rabbit kidney brush borders lies within the range considered characteristic of plasma membranes. Glossman \& Neville (1971) reported a molar ratio for cholesterol to phospholipid of 0.46 in rat kidney brush borders.

Rabbit kidney brush borders contained $126 \mu \mathrm{g}$ of carbohydrate/mg of protein and the molar proportion for amino sugars: neutral sugars: $N$-acetylneuraminic acid was 3.8:3.9:1 (Table 2). Glossmann \& Neville (1971) found somewhat lower amounts of carbohydrate $(75 \mu \mathrm{g} / \mathrm{mg}$ of protein) with a molar proportion of 4.4:6.0:1 in rat kidney brush borders. Reported values for rat liver plasma membranes of $33 \mu \mathrm{g} / \mathrm{mg}$ of protein (Benedetti \& Emmelot, 1968) and $47 \mu \mathrm{g} / \mathrm{mg}$ of protein (Henning et al., 1970) are lower. The 


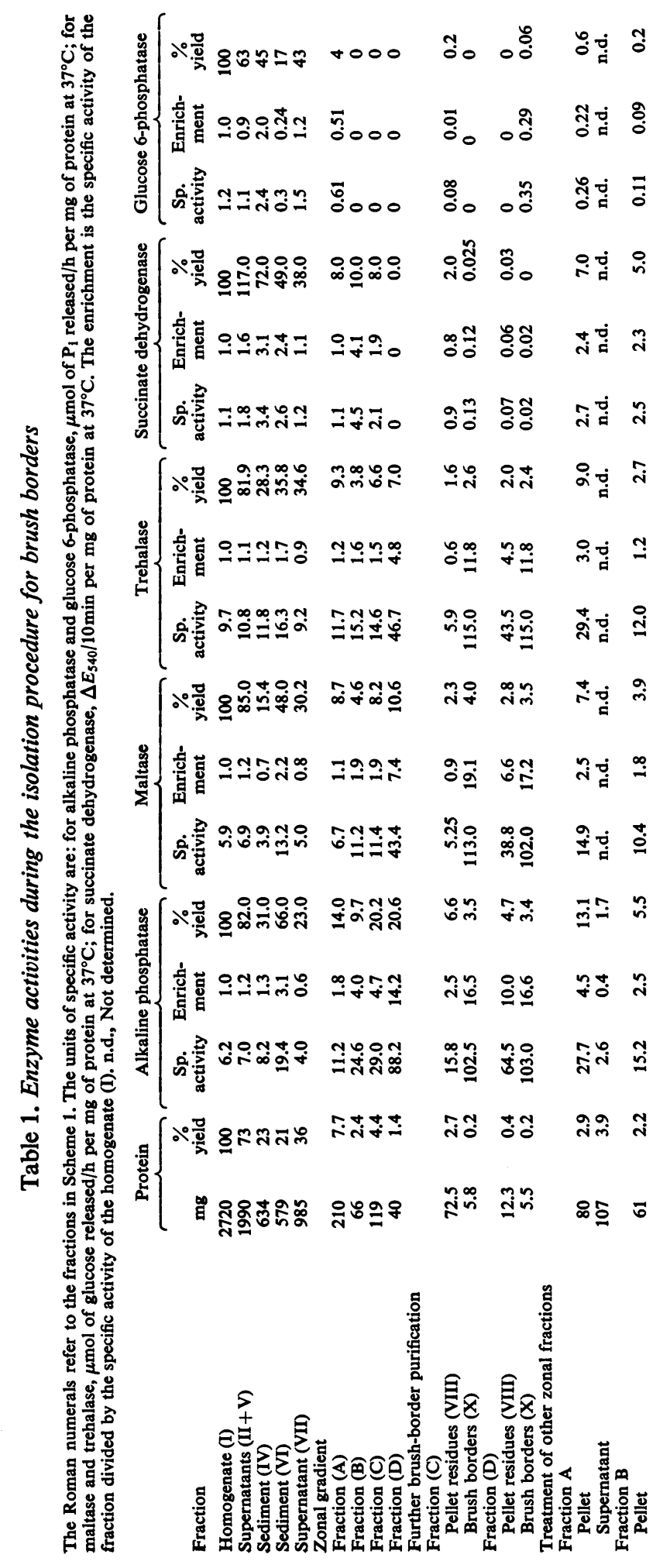


respective molar proportions obtained by these authors were 1.8:2.0:1 and 1.4:4.6:1. The proportion in rat intestinal brush borders was 12.5:23.1:1 (Forstner, 1970), but no absolute analytical values were given. Thus kidney brush borders from both rabbit and rat contain proportionately more amino sugar and $\mathrm{N}$-acetylneuraminic acid than rat intestinal brush borders, whereas the results for rat liver plasma membranes vary. The higher carbohydrate content of kidney brush borders compared with rat liver plasma membranes is no doubt partly a reflection of the more pronounced glycocalyx seen associated with kidney brush borders (Burgos, 1960; Ito, 1965; Rambourg et al., 1966; Rambourg \& Leblond, 1967; Groniowski et al., 1969). The functions of glycoproteins in membranes are not yet fully understood (Winzler, 1970); it is suggested that the glycocalyx of brush borders may act as an exclusion matrix (Pease, 1966). Whether the glycoproteins of kidney brush borders play specific roles in the function of the proximal cells is not known, but some membraneassociated enzymes such as human kidney alkaline phosphatase (Butterworth \& Moss, 1966) and $\gamma$ glutamyl transpeptidase (Spiro, 1970) are glycoproteins.

Low amounts of DNA were detected in rabbit kidney brush borders (Table 2), showing minimal contamination by nuclei. RNA amounts in the brush borders were also very low (Table 2). This material may well be derived from the small quantity of cytoplasm occasionally seen associated with the brush borders.

Enzymic evaluation. Few studies are reported of the characteristics of enzymes present in isolated kidney brush borders. Accordingly, experiments were undertaken to examine some of the properties of those enzymes which showed a high enrichment in the brush-border preparations.

Alkaline phosphatase exhibited a pH optimum at pH 10.5. $\mathrm{Mg}^{2+}(5 \mathrm{mM})$ increased the activity by $40 \%$, although a higher concentration of $\mathrm{Mg}^{2+}(10 \mathrm{mM})$ produced a lower increase in activity $(20 \%)$. EDTA (20mM) completely inhibited the enzyme, but this inhibition was prevented by $25 \mathrm{mM} \mathrm{Mg}{ }^{2+} . \mathrm{Ca}^{2+}(5 \mathrm{~mm})$ produced an activation of $15-20 \%$ and $\mathrm{Zn}^{2+}(1 \mathrm{mM})$ caused complete inhibition. A similar variety of effects with metal ions has been observed with purified mammalian alkaline phosphatase (Fernley, 1971).

Aminopeptidase, assayed with leucine $p$-nitroanilide as the substrate, had a $\mathrm{pH}$ optimum at pH7.0-7.5. $\mathrm{Co}^{2+}$ caused a slight activation $(10 \%)$ at concentrations between $0.25 \mathrm{~mm}$ and $2.0 \mathrm{~mm}$, but $1 \mathrm{mM}-\mathrm{Ca}^{2+}, \mathrm{Mg}^{2+}$ or $\mathrm{Mn}^{2+}$ had no effect. EDTA ( $5 \mathrm{~mm}$ ) caused a $20 \%$ decrease in activity and $o$ phenanthroline (1mM) caused a $90 \%$ decrease. The inhibition by $o$-phenanthroline was completely relieved by $2 \mathrm{mM}^{-\mathrm{Co}^{2+}}$, but only $20 \%$ of the original activity was restored by $2 \mathrm{~mm}-\mathrm{Mg}^{2+}, \mathrm{Mn}^{2+}$ or $\mathrm{Ca}^{2+}$.

\section{Table 2. Chemical composition of rabbit kidney brush} borders

Values are given as the mean \pm S.D. with the numbers of determinations in parentheses. Phospholipid, cholesterol, total carbohydrate and individual sugars are expressed as $\mu \mathrm{g} / \mathrm{mg}$ of protein. Phospholipid weight was obtained by multiplying the $P$ weight by 25. To calculate the cholesterol/phospholipid molar ratio, the molecular weight of phospholipid was taken as 780 . DNA is expressed as $\mu \mathrm{g}$ of DNA/mg of protein. RNA is expressed as nmol of ribose $/ \mathrm{mg}$ of protein.

$\begin{array}{lc}\text { Phospholipid } & 301 \pm 37(3) \\ \text { Cholesterol } & 97 \pm 5(3) \\ \text { Cholesterol/phospholipid molar } & 0.65 \\ \quad \text { ratio } & 126 \\ \text { Total carbohydrate } & 8.7 \pm 0.8(4) \\ \text { Fucose } & 15.8 \pm 1.9(4) \\ \text { Mannose } & 24.9 \pm 2.5(4) \\ \text { Galactose } & 2.4 \pm 0.4(4) \\ \text { Glucose } & 40.0 \pm 6.5(4) \\ \text { Glucosamine } & 10.8 \pm 2.0(4) \\ \text { Galactosamine } & 23.0 \pm 2.6(4) \\ N \text {-Acetylneuraminic acid } & 3.8: 3.9: 1 \\ \text { Amino sugar: neutral sugar: } & \\ \quad N \text {-acetylneuraminic acid } & \\ \quad \text { molar proportions } & \\ \text { DNA } & \\ \text { RNA } & \end{array}$

The aminopeptidase was therefore a $\mathrm{Co}^{2+}$-dependent enzyme, similar in properties to the particulate enzyme isolated from rat kidney by Felgenhauer \& Glenner (1966).

The disaccharidases, maltase and trehalase, had pH optima at pH6.25-6.5 and pH6.0-6.5, respectively. No metal ion requirements were found.

$\mathrm{Mg}^{2+}$-dependent adenosine triphosphatase exhibited a broad pH optimum, pH7.0-8.0, whereas the $\mathrm{Na}^{+}, \mathrm{K}^{+}$-dependent enzyme had a narrower $\mathrm{pH}$ optimum, $\mathrm{pH}$ 7.2-7.5.

The recoveries and relative enrichments of various enzymes in the brush-border preparations are shown in Table 3. Alkaline phosphatase, aminopeptidase, maltase and trehalase showed the largest enrichments compared with original homogenates and also showed the highest recoveries. Both the $\mathbf{M g}^{2+}$-dependent and $\mathrm{Na}^{+}, \mathrm{K}^{+}$-dependent adenosine triphosphatases showed modest enrichments and recoveries. Marker enzymes for other organelles, mitochondria, lysosomes and endoplasmic reticulum, were recovered in very low yields with low specific activities supporting the conclusions from the morphological studies that there was little contamination by these organelles.

The average recovery of protein was $0.63 \%(20$ 


\section{Table 3. Enzyme activities in the initial homogenate and in rabbit kidney brush borders}

Values are given as the mean \pm S.D. with the number of experiments in parentheses. Each determination was done in duplicate. The units of specific activity are: for alkaline phosphatase, the adenosine triphosphatases, glucose 6-phosphatase and acid phosphatase, $\mu \mathrm{mol}$ of $\mathrm{P}_{1}$ liberated/h per $\mathrm{mg}$ of protein at $37^{\circ} \mathrm{C}$; for maltase and trehalase, $\mu \mathrm{mol}$ of glucose liberated/h per $\mathrm{mg}$ of protein at $37^{\circ} \mathrm{C}$; for aminopeptidase, $\mu$ mol of $p$-nitroaniline liberated $/ \mathrm{h}$ per $\mathrm{mg}$ of protein at $37^{\circ} \mathrm{C}$; for succinate dehydrogenase, $\Delta E_{540} / 10 \mathrm{~min}$ per $\mathrm{mg}$ of protein at $37^{\circ} \mathrm{C}$. Enrichment is the specific activity of brush borders divided by the specific activity of the initial homogenate. Recovery is the brush-border enzyme activity expressed as a percentage of the activity of the initial homogenate.

Specific activity

\begin{tabular}{|c|c|c|c|c|}
\hline \multirow[b]{2}{*}{ Enzyme activity } & & \multirow[b]{2}{*}{ Enrichment } & \multirow{2}{*}{$\begin{array}{l}\text { Recovery } \\
(\%)\end{array}$} \\
\hline & Initial homogenate (I) & Brush borders & & \\
\hline Alkaline phosphatase (3) & $5.5 \pm 0.6$ & $104.6 \pm 3.2$ & $19.0 \pm 2.1$ & $8.0 \pm 1.1$ \\
\hline $\begin{array}{l}\mathrm{Mg}^{2+} \text {-dependent adenosine triphos- } \\
\text { phatase (5) }\end{array}$ & $6.9 \pm 2.0$ & $25.7 \pm 4.5$ & $3.7 \pm 1.1$ & $1.6 \pm 0.4$ \\
\hline $\begin{array}{l}\mathrm{Na}^{+}, \mathrm{K}^{+} \text {-dependent adenosine tri- } \\
\text { phosphatase }(5)\end{array}$ & $4.8 \pm 1.0$ & $24.2 \pm 7.6$ & $5.0 \pm 1.1$ & $2.0 \pm 0.5$ \\
\hline Aminopeptidase (2) & 10.1 & 150.2 & 15.0 & 6.3 \\
\hline Maltase (3) & $7.0 \pm 1.7$ & $113.9 \pm 21.8$ & $16.3 \pm 1.4$ & $7.0 \pm 0.6$ \\
\hline Trehalase (3) & $10.3 \pm 1.6$ & $141.5 \pm 27.3$ & $13.7 \pm 1.9$ & $5.9+1.0$ \\
\hline Succinate dehydrogenase (3) & $1.59 \pm 0.45$ & $0.16 \pm 0.11$ & $0.10 \pm 0.04$ & $0.038 \pm 0.015$ \\
\hline Glucose 6-phosphatase (3) & $1.9 \pm 0.6$ & $0.37 \pm 0.18$ & $0.19 \pm 0.05$ & $0.08 \pm 0.02$ \\
\hline Acid phosphatase (3) & $0.6 \pm 0.1$ & $0.22 \pm 0.2$ & $0.37 \pm 0.35$ & $0.13+0.11$ \\
\hline
\end{tabular}

determinations), somewhat lower than the yield of about $1.1 \%$ reported by Berger \& Sacktor (1970) for rabbit kidney brush borders. These authors reported recoveries of $0.2 \%, 0.6 \%$ and $0.1 \%$ for the marker enzymes cytochrome oxidase, $\beta$-glucuronidase and glucose 6-phosphatase; yields for equivalent marker enzymes in our preparations were $0.04 \%$ (succinate dehydrogenase), $0.13 \%$ (acid phosphatase) and $0.08 \%$ (glucose 6-phosphatase). Reports on rat kidney brush borders have not included recovery values for all the enzymes assayed making comparisons of purity difficult. Wilfong \& Neville (1970) estimated a 7\% contamination with mitochondria. The results reported by Kinne \& KinneSaffran (1969) indicate that their rat kidney brushborder preparations contained appreciable amounts of mitochondria and endoplasmic reticulum.

Since alkaline phosphatase showed the highest recovery and enrichment of all of the enzymes studied, it is relevant to consider whether this enzyme might serve as a marker enzyme for kidney brush borders. To serve as a marker, the enzyme must have a single location in a cell or cell population (de Duve, 1971). Wilfong \& Neville (1970) have proposed that alkaline phosphatase might fulfil the role of a marker enzyme for kidney brush borders since histochemical studies have indicated that the enzyme is localized in these structures (Hugon \& Borgers, 1966). However other histochemical studies have shown that the enzyme may occur at other plasma-membrane sites (Mölbert et al., 1960; Reale \& Luciano, 1967). Further, microdissection studies have shown the enzyme to be present in glomeruli, distal tubules and in the medulla as well as in the proximal tubules in dog, rat and human kidney (Bonting et al., 1958). It must therefore be concluded that the enzyme does not fulfil the necessary criterion of being restricted to a single location and is not an adequate marker enzyme, despite the high amounts in the brush-border preparations. This being so, the recovery of this enzyme ( $8 \%$ ) cannot be taken as indicating that $8 \%$ of the brush borders were recovered from the kidney cortex.

The yields and enrichments of disaccharidases in the brush-border preparations are somewhat less than those obtained for alkaline phosphatase. It may be argued that if alkaline phosphatase cannot be regarded as a marker enzyme, it follows that the disaccharidases also cannot serve this role, otherwise their recoveries would be larger than that of alkaline phosphatase. This argument assumes that the brushborder preparations contain no uncharacterized contaminant with a high alkaline phosphatase specific activity, but this seems unlikely in view of their morphological purity. It is clear from Table 1 that substantial quantities of disaccharidases are lost in supernatant (VII) and in zonal fractions (A) and (B), none of which contain recognizable brush borders. Again it can be argued that these losses are a consequence of fragmentation of brush borders. Berger \& Sacktor (1970) obtained lower recoveries of alkaline phosphatase than of disaccharidases. In view of the limited information available at present, it is not possible to decide whether disaccharidases 
can be considered as marker enzymes in kidney. Histochemical studies indicate that trehalase may be located in the basilar regions of the proximal tubule cells as well as in the distal tubule and collecting duct epithelia (Grossman \& Sacktor, 1968).

Aminopeptidase, which also shows lower recoveries and enrichments than alkaline phosphatase, cannot be regarded as a marker enzyme. Microdissection and histochemical studies show aminopeptidases at various locations within the cortex (Marsovari \& Tanka, 1969; Seligman et al., 1970; Taylor et al., 1971). There are several distinct aminopeptidases in kidney cortex active towards substrates such as Lleucine $\beta$-naphthylamide and $\mathrm{L}$-leucine $p$-nitroanilide (Nachlas et al., 1962; Beckman et al., 1966; Mattenheimer, 1967; Hanson et al., 1967a,b) and measurements of homogenate activity will include contributions from these several enzymes. Thus, measurements of recovery and enrichment of the brushborder enzyme must necessarily be approximate. About $20 \%$ of the total homogenate activity was due to soluble enzymes as distinct from particulate enzymes.

It is clear from the present studies that alkaline phosphatase, maltase, trehalase, aminopeptidase, $\mathrm{Mg}^{2+}$-dependent adenosine triphosphatase and $\mathrm{Na}^{+}, \mathrm{K}^{+}$-dependent adenosine triphosphatase are component enzymes of the kidney brush borders, even though they may not be solely located in these organelles. The adenosine triphosphatases show lower enrichments than the other enzymes and their distribution in kidney may be similar to that in intestinal epithelial cells, where Quigley \& Gotterer (1969) have shown that the specific activity of the $\mathrm{Na}^{+}, \mathrm{K}^{+}$-dependent adenosine triphosphatase in brush borders is lower than that in the basal and lateral plasma membranes. The brush borders of kidney and intestine share a common function in that they are the absorptive surfaces of epithelial cells and it is not surprising perhaps that they appear to possess a number of enzymes in common. Other absorptive and secretory cell surfaces are also known to be rich in alkaline phosphatase and aminopeptidase (Fernley, 1971; Emmelot \& Visser, 1971), suggesting that these common enzymes may fulfil an as yet unknown role in membrane function. Nevertheless it is curious that kidney brush borders should contain appreciable amounts of disaccharidases, since the substrates for these enzymes never normally appear in the glomerular filtrate.

S. J. Q. was in receipt of a Medical Research Council Scholarship for Training in Research Methods. Financial support was provided by the Cancer Research Campaign.

\section{References}

Ashworth, L. A. E. \& Green, C. (1966) Science 151, 210 Bartlett, G. R. (1959) J. Biol. Chem. 234, 466
Beckman, L., Bjorling, G. \& Christodoulou, C. (1966) Acta Genet. 16, 223

Benedetti, E. L. \& Emmelot, P. (1968) in The Membranes (Dalton, A. J. \& Haguenau, F., eds.), p. 33, Academic Press, New York and London

Berger, S. J. \& Sacktor, B. (1970) J. Cell Biol. 47, 637

Bezman-Tarcher, A., Otway, S. \& Robinson, D. S. (1965) Proc. Roy. Soc. Ser. B 162, 411

Binkley, F., King, N., Milikin, E., Wright, R. F., O'Neal, C. H. \& Wundram, I. J. (1968) Science 162, 1009

Bonting, S. L., Pollak, V. E., Muehrcke, R. C. \& Kark, R. M. (1958) Science 127, 1342

Burgos, M. (1960) Anat. Rec. 137, 171

Burton, K. (1956) Biochem. J. 62, 315

Butterworth, P. J. \& Moss, D. W. (1966) Nature (London) 209, 805

Clamp, J. R., Bhatti, T. \& Chambers, R. E. (1970) Methods Biochem. Anal. 19, 229

Coleman, R. (1968) Chem. Phys. Lipids 2, 144

Coleman, R. \& Finean, J. B. (1966) Biochim. Biophys. Acta 125, 197

Dahlqvist, A. (1968) Anal. Biochem. 22, 99

de Duve, C. (1971) J. Cell Biol. 50, 20D

Eichholz, A. (1967) Biochim. Biophys. Acta 135, 475

Emmelot, P. \& Visser, A. (1971) Biochim. Biophys. Acta 241, 273

Felgenhauer, K. \& Glenner, G. G. (1966) J. Histochem. Cytochem. 14, 401

Fernley, H. N. (1971) Enzymes, 3rd. edn., 4, 417

Fitzpatrick, D. F., Davenport, G. R., Forte, L. \& Landon, E. J. (1969) J. Biol. Chem. 244, 3561

Folch, J., Lees, M. \& Sloane-Stanley, G. H. (1957)J. Biol. Chem. 226, 497

Forstner, G. G. (1970) J. Biol. Chem. 245, 3584

Forstner, G. G., Sabesin, S. M. \& Isselbacher, K. J.(1968a) Biochem. J. 106, 381

Forstner, G. G., Tanaka, K. \& Isselbacher, K. J. (1968b) Biochem. J. 109, 51

Glossmann, H. \& Neville, D. M. (1971) J. Biol. Chem. 246, 6339

Groniowski, J., Biczyskowa, W. \& Walski, M. (1969) J. Cell Biol. 40, 585

Grossman, I. W. \& Sacktor, B. (1968) Science 161, 571

Hanson, V. H., Hütter, H.-J., Mannsfeldt, H.-G., Kretschmer, K. \& Sohr, C. (1967a) Hoppe-Seyler's Z. Physiol. Chem. 348, 680

Hanson, V. H., Glasser, D., Ludewig, M., Mannsfeldt, H.-G. \& John, M. (1967b) Hoppe-Seyler's Z. Physiol. Chem. 348, 689

Henning, R., Kaulen, H. D. \& Stoffel, W. (1970) HoppeSeyler's Z. Physiol. Chem. 351, 1191

Hübscher, G. \& West, G. R. (1965) Nature (London) 205, 799

Hugon, J. \& Borgers, M. (1966) J. Histochem. Cytochem. 14,429

Ito, S. (1965) J. Cell Biol. 27, 475

Keenan, T. W. \& Morré, D. J. (1970) Biochemistry 9, 19

King, E. J. (1932) Biochem. J. 26, 292

Kinne, R. \& Kinne-Saffran, E. (1969) Pflügers Arch. 308, 1

Kopaczyk, K., Perdue, J. \& Green, D. E. (1966) Arch. Biochem. Biophys. 115, 215

Lowry, O. H., Rosebrough, N. J., Farr, A. L. \& Randall, R. J. (1951) J. Biol. Chem. 193, 265

Vol. 128 
Manitus, A., Bensch, K., \& Epstein, F. H. (1968) Biochim. Biophys. Acta 150, 563

Marsovari, I. \& Tanka, D. (1969) Klin. Wochenschr. 21, 1178

Mattenheimer, H. (1967) Curr. Probl. Clin. Biochem. 2 (Enzymes Urine Kidney, Proc. Int. Conf. 1967), 119

Miller, D. \& Crane, R. K. (1961) Biochim. Biophys. Acta 52, 293

Mölbert, R. G., Duspiva, F. \& von Deimling, O. H. (1960) J. Biophys. Biochem. Cytol. 7, 387

Nachlas, M. N., Goldstein, T. P. \& Seligman, A. M. (1962) Arch. Biochem. Biophys. 97, 223

Pease, D. C. (1966) Anat. Rec. 154, 400

Pennington, R. J. (1961) Biochem. J. 80, 649

Pitts, R. F. (1968) Physiology of the Kidney and Body Fluids, 2nd. edn., p. 97, Year Book Medical Publishers, Chicago

Quigley, J. P. \& Gotterer, G. S. (1969) Biochim. Biophys. Acta 173, 456

Rambourg, A. \& Leblond, C. P. (1967) J. Cell Biol. 32, 27
Rambourg, A., Neutra, M. \& Leblond, C. P. (1966) Anat. Rec. 154, 41

Ray, T. K., Skipski, V. P., Barclay, M., Essner, E. \& Archibald, F. M. (1969) J. Biol. Chem. 244, 5528

Reale, E. \& Luciano, L. (1967) J. Histochem. Cytochem. 15,413

Rhodin, J. (1958) Int. Rev. Cytol. 7, 485

Schneider, W. C. (1957) Methods Enzymol. 3, 680

Seligman, A. M., Wasserkrug, H. L., Plapinger, R. E., Selto, T. \& Hanker, J. S. (1970) J. Histochem. Cytochem. 18, 542

Spiro, R. G. (1970) Annu. Rev. Biochem. 39, 599

Stadtman, T. C. (1957) Methods Enzymol. 3, 392

Taylor, D. G., Price, R. G. \& Robinson, D. (1971) Biochem. J. 122, 641

Thuneberg, L. \& Rostgaard, J. (1968) Exp. Cell Res. 51, 123

Touster, O., Aronson, N. N., Dulaney, J. T. \& Hendrickson, H. (1970) J. Cell Biol. 47, 604

Wilfong, R. F. \& Neville, D. M. (1970) J. Biol. Chem. 245, 6106

Winzler, R. J. (1970) Int. Rev. Cytol. 29, 77 